\title{
Comparing multi-criteria methods for landslide susceptibility mapping in Chania Prefecture, Crete Island, Greece
}

\author{
M. Kouli ${ }^{1}$, C. Loupasakis ${ }^{2}$, P. Soupios ${ }^{1}$, D. Rozos ${ }^{2}$, and F. Vallianatos ${ }^{1}$ \\ ${ }^{1}$ Laboratory of Geophysics and Seismology, Department of Natural Resources and \\ Environment, Technological Educational Institute of Crete, Chania, Crete, Greece \\ ${ }^{2}$ Laboratory of Engineering Geology and Hydrogeology, Department of Geological Sciences, \\ School of Mining and Metallurgical Engineering, National Technical University of Athens, \\ Zografou Campus, Greece
}

Received: 8 January 2013 - Accepted: 16 January 2013 - Published: 29 January 2013

Correspondence to: M. Kouli (mkouli@ chania.teicrete.gr)

Published by Copernicus Publications on behalf of the European Geosciences Union.

\begin{abstract}
In this work, two multi-criteria methods, an expert-based, semi-quantitative, relative weighting - rating approach, the weighted linear combination (WLC) and a quantitative, statistical method, the weights of evidence (WoE) approach were applied for landslide 5 susceptibility zonation mapping in the Chania Prefecture of Crete Island, Greece. Several thematic maps representing various landslide casual factors, such as geological formations, faults proximity, elevation, slope gradient, aspect and curvature, rivers proximity, precipitation, roads proximity and land use types; have been generated in a GIS environment. Two landslide susceptibility maps were created; one for each method.

${ }_{10}$ The maps were compared and validated using the success rate curve (SRC) analysis. The resulting landslide susceptibility maps have uncertainties introduced due to the subjective knowledge of experts in the case of WLC method and to the quality of the recorded landslides sample in the case of the WoE method. Both approaches produced almost equally accurate maps with the WoE method to produce slightly superior 15 predictions.
\end{abstract}

\section{Introduction}

Landslides are the most commonly occurring geological hazards worldwide and the second most frequent natural catastrophic events, after hydro-meteorological events. Landslides are considered to be one of the most catastrophic natural hazards due to 20 the fact that they cause extensive damages to constructions and infrastructures as well as thousand casualties annually (Saha et al., 2002; Akgun and Turk, 2007).

Landslide hazard assessment and risk reduction can be accomplished by providing the risk managers with easy accessible, continuous, and accurate information about the landslide susceptibility. Thus, an accurate susceptibility mapping can be the key information for a large variety of users from both private and public sectors, from 
governmental departments and the scientific community and from local to international levels.

A landslide susceptibility map depicts areas likely to have landslides in the future by correlating some of the principal factors that contribute to landslides with the past 5 distribution of slope failures (Brabb, 1984; Fall et al., 2006). Crucial factors for the construction of reliable susceptibility maps are the quality and the amount of available data and the selection of the best methodology analysis. The process of creating these maps involves different approaches and methods distinguished as: qualitative, semi-quantitative and quantitative (Lee and Jones, 2004; Castellanos Abella and

10 van Westen, 2008). Quantitative methods are based on mathematical expressions of the correlation between controlling factors and landslides. The two types of commonly used quantitative methods are the deterministic and the statistical (Ward et al., 1981; Nash, 1987; Terlien et al., 1995; Kramer, 1996; Atkinson and Massari, 1998; Aleotti and Chowdhury, 1999; Fall and Azzam, 2001a, b; Akgun and Bulut, 2007). The statisti15 cal approach uses statistical and probabilistic methods. According to these methodologies the previous landslides can be related to measurable elements of the landscape (Koukis and Ziourkas, 1991; Dai et al., 2002; Ohlmacher and Davis, 2003; Akgun and Bulut, 2007) and these elements can be used to predict possible future landslides. Typical multivariate statistical approaches used to map landslide susceptibility are the

20 weight of evidence (WoE) modeling method, a quantitative "data-driven" method used to combine datasets (Lee et al., 2002; van Westen and Lulie, 2003; Lee et al., 2004a; Thiery et al., 2007; Mathew et al.,. 2007; Neuhauser and Terhorst, 2007; Poli and Sterlacchini, 2007; Rezaei Moghaddam et al., 2007; Dahal et al., 2008a, b; Sharma and Kumar, 2008; Barbieri and Cambuli, 2009; Ghosh et al., 2009; Regmi et al., 2010) and 25 the logistic regression method (Wieczorek, 1996; Atkinson and Massari, 1998; Guzzetti et al., 1999; Gorsevski et al., 2000; Lee and Min, 2001; Dai et al., 2001; Dai and Lee, 2002; Ohlmacher and Davis, 2003; Ayalew and Yamagishi, 2005).

Qualitative methods are based on expert opinions (Nash, 1987; Anbalagan, 1992; Fall et al., 1996; Evans et al., 1997; Leroi, 1997; Atkinson and Massari, 1998; Guzzetti

et al., 1999; Fall et al., 2006). The basic types of qualitative methods simply use landslide index to identify areas with alike geological and geomorphologic characteristics that are susceptible to landslides. However, there are qualitative methodologies which use weighting and rating and are regarded to be semi quantitative (Hutchinson and 5 Chandler, 1991; Siddle et al., 1991; Moon et al., 1992; Fell et al., 1996; Ayalew and Yamagishi, 2005, Kouli et al., 2010). Such kinds of methodologies are the analytic hierarchy process (AHP) by Saaty, 1980; Barredo et al., 2000; Yalcin, 2008; Mondal and Maiti, 2012 and the weighted linear combination (WLC) (Ayalew et al., 2004a, b; Ayalew et al., 2005; Kouli et al., 2010).

$10 \quad$ Furthermore, during the last decades, many studies (such as van Westen, 1994; Carrara et al., 1995; Aleotti and Chowdhury, 1999; Dai et al., 2002; Cevik and Topal, 2003; Ayalew and Yamagishi, 2005; Fall et al., 2006; Carrara and Guzzetti, 1995; Carrara et al., 1995; Dikau et al., 1996; Luzi et al., 2000; Miles and Ho, 1999; Miles and Keefer, 1999; Carrara et al., 1999; Fall, 2000; Refice and Capolongo, 2002; Fall et al., 15 2006; Kouli et al., 2010; Arnous, 2011) have been carried out to overview the use of GIS for landslide susceptibility assessment.

In a geologically active country like Greece the intensive tectonic activity is not related only to earthquake events but also to other natural hazards. Active tectonics generates steep morphological structures, strained geological formations and intensive

20 weathering procedures which are considered to be the main causal factors of landslide events.

Crete Island is located in the southern part of the Hellenic fore-arc, an area of important tectonic deformation and high seismic activity. This high seismic activity is caused by the subduction of the oceanic African lithosphere beneath the continental Anatolian-

25 Aegean lithosphere (Papazachos and Comninakis, 1971; McKenzie, 1972; Angelier, 1979; Makropoulos and Burton, 1984).

Chania Prefecture, located at the western part of the Island (Fig. 1), suffers from severe landslide phenomena. The lack of a landslide susceptibility mapping in the approximately $2330 \mathrm{~km}^{2}$ study area makes the risk management impossible for the local 
authorities. The landslide susceptibility analysis introduced in this study covers the entire Chania Prefecture and it is conducted by the application of the Weight of Evidence (WoE) statistical modeling method and the Weighted Linear Combination (WLC) semi quantitative approach. Besides the obvious benefit of providing landslide susceptibility

5 maps, the study compares the efficiency of the applied methods.

\section{Geological framework of Chania prefecture}

Crete Island is characterized by an extremely complicated geological structure with intensive tectonic fragmentation. Although many researchers through the years have studied the geological evolution of the island (Tataris and Christodoulou, 1965; Bonneau, 1973; Creutzburg, 1977; Fitrolakis, 1980; Tsiampaos, 1989), there are still many unsolved issues. Based on current theories, the island constitutes of repeated tectonic covers consisting of variant geotectonic zones' geological series.

Considering the surficial geology of Chania prefecture (Fig. 2), Quaternary deposits forming depositional plains dominate especially at the northern part of the study area,

15 as well as along the coast line. Miocene to Pliocene sediments crop out in the central and the northwestern part of the study area and carbonates of the Tripolis nappe in the northeastern part. Dissected hills of phyllites and quartzites, a late Carboniferous to late Triassic package of sedimentary rocks composed mostly of quartz-rich siliciclastic sediments, with minor limestone, gypsum, and volcanic rocks (Krahl et al., 1983) cover

20 the central part of the study area. Carbonates of the Trypalion nappe are exposed in the central-eastern part of the Chania Prefecture, extending from the north to the south, with a NE-SW direction. Limestones of the Plattenkalk zone are mainly exposed to the most southeastern part of the study area. The tectonic regime of the study area is characterized by faults in NW-SE and E-W directions.

\section{Data layers-landslides casual factors}

Geological, topographical, land use and precipitation data were collected and introduced in a Geographic Information System (GIS). By processing the primary data layers the following landslide casual factors were selected and prepared as secondary

5 data layers: unified lithology, faults proximity, elevation, slope gradient, aspect and curvature, roads and rivers proximity, precipitation, and land use types.

The geological maps of the Institute of Geology and Mineral Exploration (IGME) presenting lithological and structural units, at a scale of $1: 50000$ were digitized. The Digital Elevation Model, with a cell size of $20 \mathrm{~m}$, was generated from the topographic

10 maps of the Hellenic Military Geographical Service, at a scale of 1:50000. Many terrain attributes such as slope angle, aspect, curvature and stream network were computed using the digital elevation model. Furthermore, the Corine Land Cover map 2000 (CLC2000 100 m, version 1) of the European Environment Agency (EEA, Copenhagen, 2000; http://www.eea.europa.eu) was adopted for the assignment of the land

15 use classes. Precipitation data covering a time period of $25 \mathrm{yr}$ were also introduced in the GIS. The landslide inventory map of 108 landslide locations was created using data coming up from field investigation, previously documented events and Google Earth satellite images interpretation (Fig. 3). At the inventory map all the landslides are introduced as points because of the small scale enforced by the great extent of the

20 study area. All thematic maps were generated using ArcGIS Desktop 9.1 software. All the raster layers were resampled using a cell size of $20 \times 20 \mathrm{~m}$.

\subsection{Unified lithology}

The geological formations type and condition are closely related to the landslide occurrence. Considering the landslide susceptibility, the geological formations occupying 25 the Chania prefecture (IGME, 1956, 1969, 1970, 1971, 1982, 1988, 1993a, 2002) were classified into five classes, ranging from the highest to the lowest susceptibility class as follows: (a) flysch formations, (b) phyllites - quartzites unit (presenting thick weathering 
mantle), (c) loose Quaternary deposits, (d) Neogene formations and (e) limestones and marbles. The weighting-rating values set to the above mentioned classes are clearly presented in Table 1.

The formations of the first four classes compose of alternating layers with grate vari5 ations in their mechanical and permeability properties setting the preparatory causal factors (Terzaghi, 1950; Popescu, 1994) for the manifestation of translational landslides or creep movements. On the contrary, at the areas occupied by limestones and marbles only rock falls, determined by the fragmentation degree of the rock mass, can be expected (Fig. 3).

\section{$10 \quad 3.2$ Faults proximity}

Tectonic structures associate with extensive fractured zones and steep relief anomalies, especially in rock formations. As a result these zones present favorable conditions for the manifestation of landslides. Therefore, major tectonic structures, digitized from the IGME geological maps, were included as a secondary data layer in this study.

15 For the introduction of the tectonic structures influence, multiple buffer zones were generated around the faults lineament, at distances of 100 and $200 \mathrm{~m}$ (Fig. 4). The three classes generated by means of the above described procedure were rated accordingly, as presented in Table 1.

\subsection{Land use types}

20 Land use is also related with the triggering and preparatory causal factors of the landslides. For instance, the strong root system of the woody vegetation provides both hydrological and mechanical effects that generally stabilize slopes. As a result, the landslide events recorded in woodlands are much less than those of the un-vegetated or irrigated cultivated areas.

The role of vegetation in the slope stability was introduced by rating the main land use classes of Chania prefecture, as mentioned at the Corine Land Use map 2000. The eight main land use classes were ranked as shown in Table 1.

\subsection{Rivers proximity}

5 The density of the drainage network is considered as an important factor in characterizing landslide susceptible areas. Fluvial erosion is one of the most common triggering causal factors of the landslides (WP/WLI, 1994), and it usually affects the slopes toe.

In this case study the drainage network was automatically extracted from the DEM and the drainage tributaries were classified according to Strahler's system (Strahler, 10 1957, 1964).

A drainage network buffer zones data layer was produced considering the streams order (Fig. 4). Generally the streams of each order were multiply buffered at two to three distances giving rise to three to four classes, respectively. The multiple buffer zones applied in each steam order as well as the rating values are analytically presented in 15 Table 1

\subsection{Slope angle and curvature}

Slope geometry is a vital controlling factors in slope stability (Huang and Li, 1992; Wu et al., 2001), and a digital slope image is therefore a fundamental part of a hazard assessment model (Clerici et al., 2002; Saha et al., 2002; Cevik and Topal, 2003;

20 Ercanoglu and Gokceoglu, 2004; Lee et al., 2004a, b; Yalcin, 2008). Slope angle was extracted from the DEM, and the derived slope angle map saw values ranging from $0^{\circ}$ to $84^{\circ}$. The produced slope image was reclassified into six slope angle classes $\left(0^{\circ}-5^{\circ}\right.$, $6^{\circ}-15^{\circ}, 16^{\circ}-30^{\circ}, 31^{\circ}-45^{\circ}$, and $>45^{\circ}$ ) (Table 1; Fig. 5).

Similarly, slope curvature has a strong influence on slope stability as in steep ter25 rain either concentrates or disperses surface and subsurface water in the landscape 
(Kayastha et al., 2012). Slope curvature was classified into three classes namely convex, flat and concave.

\subsection{Slope aspect}

The slope aspect is defined as the downslope direction of the maximum rate of eleva5 tion change. Aspect can influence indirectly the landslide initiation because it controls the exposition to several climate conditions (duration of sunlight exposition, precipitation intensity, moisture retention, etc.) and as a result the vegetation cover (Wieczorek et al., 1997; Dai et al., 2002; Cevik and Topal, 2003; Suzen and Doyuran, 2004; Komac, 2006).

10 Considering that in Greece, because of the major mountain chains orientation, the NW oriented slopes are more violently affected by rainfalls, the slope aspect was classified accordingly. The nine slope aspect classes presented in Table 1 allow the application of rating values covering all possible climate conditions exposition.

\subsection{Elevation}

15 The elevation is a parameter secondarily related to the landslide occurrence. For instance, the high relief areas are usually occupied by the most cohesive formations (e.g., limestones), they are exposed in unfavorable climate conditions (e.g. intensive rainfalls), they are uninhabited and landslide events rarely take place and even more relay are recorded there. The low elevation areas occupied by Quaternary and Neo20 gene sediments, depending on the roughness of the morphology, can present low to very high landslide frequency. So there is not any general rule relating the landslide occurrence with the elevation. The reclassification of the elevation data layer and the rating values of the classes are highly depended on the expert's opinion. The expert has to correlate as many geological and morphological factors as possible with the

25 elevation in order to introduce correctly the elevation data layer to the Geographic Information System (GIS).

In this study the higher rating values were given to the classes covering the elevations from 700 to $1000 \mathrm{~m}$ (Table 1), presenting steep morphology and mainly occupied by flysch formations and the phyllites - quartzites unit.

\subsection{Precipitation}

5 High precipitation is characterized as the physical processes constituting the main triggering causal factors of landslides (WP/WLI 1994; Koukis et al., 1997; Polemio and Sdao, 1999; Sdao and Simeone, 2007). For this work, precipitation data for a timeperiod of about $25 \mathrm{yr}$ were collected from three different agencies; the Department of Hydrology and Water Resources - Crete Region (DHWR-CR), the National Agricultural

10 Research Foundation located in Chania in Crete Island (NAGREF) and the Branch of the Institute of Geology and Mineral Exploration situated in Rethymnon in Crete Island (IGME) (Kouli et al., 2009). The average annual precipitation of the study area ranges from 800 to $1400 \mathrm{~mm}$. Three classes were defined, using an equal interval of $200 \mathrm{~mm}$ (Table 1).

\section{$15 \quad 3.9$ Roads proximity}

Road construction is related to extensive excavations, application of static and dynamic loads, vegetation removal etc. along natural and engineered slopes. These landslide triggering actions (WP/WLI 1994) were considered in the design of the landslide susceptibility maps by introducing a road network buffer zones data layer.

20 Multiple buffer zones were applied, within distances of 20,50 and $100 \mathrm{~m}$, to the road network producing four classes (Table 1).

\section{Methodologies}

At a first step, an expert based, relative weighting - rating approach (WLC) was used for the landslide susceptibility mapping. According to this method, certain weights (Table 1) 
were assigned to each factor by taking into account the specific landslide occurrence parameters of the study area. The lithology-based weighting-rating system introduced in Kouli et al. (2010) was adopted as it was proved to be satisfactory accurate. After that, the rating values assigned to the different classes of the factors thematic layers 5 were introduced as attribute information in the GIS and an "attribute map" was generated for each data layer representing a causative factor. The vector data layers were reclassified using the assigned rates and the related raster data layers were produced. Finally, the reclassified raster layers were used as input parameters for the raster calculator function. By means of the raster calculation the lithology-based weighted factor

10 maps were overlaid (summed) to provide the landslide susceptibility maps.

Moreover, the weight of evidence (WoE) method was applied using the $80 \%$ of the inventory map landslides as the training set and the rest $20 \%$ for accuracy assessment purposes.

The weight of evidence (WoE) modeling method was firstly developed for medicine

15 purposes (Spiegelhater and Knill-Jones, 1984), but it was also applied to the identification of mineral deposits potential (Bonham-Carter et al., 1988, 1989), to landslide susceptibility mapping (Lee et al., 2002; van Westen et al., 2003; Lee and Choi, 2004; Thiery et al., 2004, 2007; Mathew et al., 2007; Neuhauser and Terhorst, 2007; Poli and Sterlacchini, 2007; Rezaei Moghaddam et al., 2007; Dahal et al., 2008a, b; Sharma 20 and Kumar, 2008; Barbieri and Cambuli, 2009; Ghosh et al., 2009; Regmi et al., 2010; Kayastha et al., 2012; Xu et al., 2012; Armas, 2012) and most recently to groundwater mapping (Lee et al., 2012).

Bonham-Carter et al. $(1988,1989)$ gave a detailed description of the mathematical formulation of the method. Weights for each landslide predictive factor are calculated based on the presence or absence of landslides within the different classes of a causative factor (Kayastha et al., 2012):

$$
\begin{aligned}
& W^{+}=\ln \frac{P\{F \mid L\}}{P\{F \mid \bar{L}\}} \\
& W^{-}=\ln \frac{P\{\bar{F} \mid L\}}{P\{\bar{F} \mid L\}}
\end{aligned}
$$

where $W^{+}$and $W^{-}$are the weights for the presence or absence of landslides within 5 a certain class of a causative factor map, $P\{A \mid B\}$ is the conditional probability of $A$ occurring given the presence of $B, F$ signifies the presence of a landslide, $L$ is a class of a causative factor, and the bar above a symbol signifies the negation (Kayastha et al., 2012). Applied to the landslide susceptibility estimation, the technique of log-likelihood ratios aims to identify the degree of influence, expressed as "weight" that each variable

10 has on the development of a landslide event (Barbieri and Cambuli, 2009). Weights are calculated based on the spatial development of landslides in the thematic maps used as evidence.

The statistical significance of the weights can be verified based on their variances, $S^{2}\left(W^{+}-W^{-}\right)$, which can be estimated as (Bonham-Carter, 1994):

$$
\begin{aligned}
W^{+} & =\ln \frac{N\{F \cap L\} N\{L\}}{N\{F \cap \bar{L}\} N\{\bar{L}\}} \\
W^{-} & =\ln \frac{N\{\bar{F} \cap L\} N\{L\}}{N\{\bar{F} \cap \bar{L}\} N\{\bar{L}\}}
\end{aligned}
$$

The contrast, $C=W^{+}-W^{-}$for a given class provides a measure of the correlation between the class of a causative factor and the occurrence of landslides. It measures the degree of correlation between point pattern and binary map, and can be tested for statistical significance (Agterberg and Cheng, 2002). For a spatial relation, the value of $C$ is positive, and when a spatial relationship is lacking, the value is negative. When 
the landslides are randomly distributed within the study area, then $W^{+}=W^{-}$and $C=0$. The variance of the contrast, $S^{2}(C)$, is given by the sum of $S^{2}\left(W^{+}\right)$and $S^{2}\left(W^{-}\right)$, and the studentised contrast, $C / S(C)$, gives a measure of confidence (Neuhäuser and Terhorst, 2007). The higher the studentised contrast the stronger the relationship between the

5 causative factor class and the occurrences of landslides. If the studentised contrast is high, there is likely a positive spatial association between the occurrence of landslides and the causative factor class while if the studentised contrast is small, the causative factor class disfavors the occurrence of landslides.

\section{Landslide susceptibility maps - results}

10 The landslide susceptibility maps with both WLC and WoE methods were produced within a raster/grid GIS and were reclassified into low, moderate, high and very high susceptible zones, using the natural breaks classification method.

The Landslide Hazard Index (LHI) for each grid cell is given by the summation of the raster thematic maps after their multiplication by the corresponding weights. In

15 the case of WLC method, the Landslide Hazard Index (LHI) for each grid cell was extracted by the summation of the raster thematic maps after their multiplication by the corresponding lithology-based weights (Kouli et al., 2010) as shown in Table 1. The LHI is presented by the expression as given below:

${ }_{20} \mathrm{LHI}=\sum_{i=1}^{n}$ Weight $_{w 1} \times$ ClassRate (Kouli et al., 2010),

where $n$ is the total number of causative factors.

In the case of WoE application, the hazard index maps were obtained by combining the contrasts of each causative factor according to the following equation:

${ }_{25} \mathrm{LHI}=\sum_{i=1}^{n} C_{j i} \quad$ (Kayastha et al., 2012),

where $C_{i j}$ is the contrast value for class $j$ for the causative factor $i$ and $n$ is the total number of causative factors.

The resulting landslide susceptibility maps are shown in Figs. 6 and 7, respectively.

The weights, variances, contrasts and studentised contrasts for all parameter classes 5 after the application of the WoE method are presented in Table 2. According to this table and having in mind that high weights indicate high probability of landslide occurrence, the distance to roads and geology casual factors mainly govern the landslide phenomena in the study area while distance to rivers, slope curvature and elevation play an important role. As it seems the most significant causative factors classes with

10 a positive impact on landslides are: (a) slope angle of $16^{\circ}-30^{\circ}$, (b) slope aspect NW, (c) slopes of concave shape, (d) areas with elevation 200-400 m, (e) distance from rivers $20-100 \mathrm{~m}$, (f) land uses of forest and heterogeneous agricultural areas, $(\mathrm{g})$ the geological formations of phyllites-quartzites and flysch, (h) distance from faults 200$400 \mathrm{~m}$, (i) precipitation of $800-1000 \mathrm{~mm} \mathrm{yr}^{-1}$ and (j) areas proximal to roads (distance $15<100 \mathrm{~m}$ ). Respectively, the most significant parameter classes with a negative impact on landslides are: (a) slope angle $0^{\circ}-5^{\circ}$, (b) slope aspect $E$, (c) the geological formation of Plattenkalk limestones, (d) elevation less than $200 \mathrm{~m}$, (e) distance from drainage more than $100 \mathrm{~m}$, (f) land use of permanent crops and scrub and /or herbaceous vegetation associations, (g) distance from faults greater than $400 \mathrm{~m}$, (h) precipitation more 20 than $1200 \mathrm{~mm} \mathrm{yr}^{-1}$ and (i) distance from roads $>500 \mathrm{~m}$.

The above mentioned impact of the causative factor on the landslides occurrence appears to be reasonable. But a detailed examination of the WoE method results reviles some irregularities. For example, the existence of forests appears to have positive impact on the landslide occurrence, fact totally unacceptable. Obviously numerous 25 roads intersect areas characterized as forests at the Corine Land Cover map confusing the WoE method results. Another obscurity of the WoE method is that the $C_{i j}$ values are strongly related to the quality of the landslide sample. Usually the landslides are recorded when they damage the road network, villages and, in general, when they interrupt the human activities. So usually the available sample of landslides 
is not representative. These irregularities appear to introduce a random error at the Landslide Hazard Index values.

According to Rossi et al. (2010), a combination of the two landslide susceptibility maps was produced using the logistic regression approach. For this purpose, the pres-

5 ence or absence of the landslides in the study area was the dependent variable, while the two landslide susceptibility maps were the independent explanatory variables. The resulted combined map is shown in Fig. 8.

\section{Validation of the applied methods - success rate curves}

In order to proceed to the validation of the landslide susceptibility maps the suc10 cess rate curves (Chung and Fabbri, 1999; van Westen et al., 2003; Kayastha et al., 2012) were adopted. The "areas under the curves" constitutes one of the most commonly used accuracy statistics for the prediction models in natural hazard assessments (Begueria, 2006). The rate explains how well the model predicts the landslide (Chung and Fabbri, 1999) and the area under the curve can be used to assess the prediction

15 accuracy qualitatively (Fig. 9). The cumulative percentage of observed landslide occurrence was plotted against the real cumulative percentage in decreasing $\mathrm{LHI}$ values to obtain the success rate curve for the study area. The rate curves were created and the "areas under the curves" were calculated for the three cases of hazard maps using the existing landslide location data. For example, in the case of the WoE, the $10 \%$ of the

20 study area can explains $67 \%$ of all the landslides in the success rate and was classified as a zone of very highly susceptibility while at the same time the same $10 \%$ of the study area can explain $53 \%$ of all the landslides in te case of WLC method. Therefore, it is obvious that the WoE method resulted in better predictions (success rate of $87.4 \%$ ) compared to the WLC method (success rate of $84.7 \%$ ). The combined model shows $2585 \%$ area under curve reducing the uncertainties introduced to the WLC method by subjective knowledge of experts.

\section{Conclusions}

For the Chania Prefecture area two landslide susceptibility maps were produced adopting the weighted linear combination (WLC) and the weights of evidence (WoE) methods. A third map was produced from the combination of the two methods using the

5 logistic regression approach. The produced landslide susceptibility maps are substantial for the land degradation management and planning of the study area and they clearly present the areas prone to landslides. The validation procedure confirmed the index setup procedure of both WLC and WoE methods and as a result the accuracy of the indicated hazardous areas. So both methods provided accurate susceptibility

10 maps which they can be used safely from the local authorities for slope management and land-use planning. It must be noted that the WoE method provided more accurate results despite the limited inventory data. The current study also proved that, despite the subjectiveness introduced to the WLC method by utilizing the knowledge of experts, the produced susceptibility maps can be proved to be satisfactory accurate. The

15 combined model resulted to the smoothing and balancing of the output susceptibility maps but it did not overcome the prediction accuracy of WoE. Nevertheless, in cases where the quality of the available inventory data is considered satisfactory and the landslide sample is statistically adequate, the combination of both methods can be proved significant for the crosschecking of the results and the tracing of any possible mistakes.

20 Acknowledgements. The project is co-funded by the European Social Fund and National Resources in the framework of the project THALIS MIS 80198, entitled "GeocharacterizationGeotechnical characterization of selected areas in Crete using geophysical and geotechnical methods", WP-2. 2.

\section{References}

25 Agterberg, F. P. and Cheng, Q.: Conditional independence test for weights of evidence modelling, Natural Resour. Res., 11, 249-255, 2002 
Akgün, A. and Bulut, F.: GIS-based landslide susceptibility for Arsin-Yomra (Trabzon, North Turkey) region, Environ. Geol., 51, 1377-1387, doi:10.1007/s00254-006-0435-6, 2007.

Akgun, A. and Türk, N.: Landslide susceptibility mapping for Ayvalik (Western Turkey) and its vicinity by multicriteria decision analysis, Environ. Earth Sci., 61, 595-611, doi:10.1007/s12665-009-0373-1, 2010.

Aleotti, P. and Chowdhury, R.: Landslide hazard assessment: summary review and new perspectives, Bull. Eng. Geol. Environ., 58, 21-44, 1999.

Anbalagan, D.: Landslide hazard evaluation and zonation mapping in mountainous terrain, Eng. Geol., 32, 269-277, 1992.

10 Angelier, J.: Determination of the mean principal directions of stresses for a given fault population, Tectonophysics, 56, T17-T26, 1979.

Armaş, I.: Weights of evidence method for landslide susceptibility mapping, Prahova Subcarpathians, Romania, Nat. Hazards, 60, 937-950, doi:10.1007/s11069-011-9879-4, 2012.

Arnous, M.: Integrated remote sensing and GIS techniques for landslide hazard zonation: a case study Wadi Watier area South Sinai, Egypt, J. Coast Conserv., 15, 477-497, 2011.

Atkinson, P. M. and Massari, R.: Generalized linear modeling of landslide susceptibility in the central Apennines, Italy, Comput. Geosci., 24, 373-385, 1998.

Ayalew, L. and Yamagishi, H.: The application of GIS-based logistic regression for landslide susceptibility mapping in the Kakuda-Yahiko Mountains, Central Japan, Geomorphology, 65, 15-31, 2005.

Ayalew, L., Yamagishi, H., and Ugawa, N.: Landslide susceptibility mapping using GIS-based weighted linear combination, the case in Tsugawa area of Agano River, Niigata Prefecture, Japan, Landslides, 1, 73-81, 2004a.

Ayalew, L., Yamagishi, H., Watanabe, N., and Marui, H.: Landslide susceptibility mapping using a semi-quantitative approach, a case study from Kakuda-Yahiko Mountains, Niigata, Japan, in: Proceedings of the 4th Asian Symposium on Engineering Geology and the Environment, edited by: Free, M. and Aydin, A., Geological Society of Hong Kong, 7, 99-105, 2004b.

Barbieri, G. and Cambuli, P.: The weight of evidence statistical method in landslide susceptibility mapping of the Rio Pardu Valley (Sardinia, Italy), 18th World IMACS/MODSIM Congress, Cairns, Australia, 2658-2664, 2009.

Barredo, J. I., Benavides, A., Hervas, J., and Van Westen, C. J.: Comparing heuristic landslide hazard assessment techniques using GIS in the Tirajana basin, Gran Canaria Island, Spain, Int. J. Appl. Earth Observation Geoinf., 2, 9-23, 2000.

Begueria, S.: Validation and evaluation of predictive models in hazard assessment and risk management, Nat. Hazards, 37, 315-329, 2006.

Bonham-Carter, G. F.: Geographic Information Systems for Geoscientists, Modeling with GIS, Pergamon Press, Oxford, 1994.

5 Bonham-Carter, G. F., Agterberg, F. P., and Wright, D. F.: Integration of geological datasets for gold exploration in Nova Scotia, Photogramm. Eng. Remote Sens., 54, 1585-1592, 1988.

Bonham-Carter, G. F., Agterberg, F. P., and Wright, D. F.: Weights of evidence modelling: a new approach to mapping mineral potential, Statistical applications in the earth science, geological survey of Canada, Paper 89-9, 171-183, 1989.

10 Bonneau, M.: Les différentes "séries ophiolitiferes" de la Crète: une mise au point, C.R. Acad Sc., 276, 1249-1252, 1973.

Brabb, E. E.: Innovative approaches to landslide hazard and risk mapping. Proc., Fourth International Symposium on Landslides, Canadian Geotechnical Society, Toronto, Canada, 1, 307-324, 1984.

15 Carrara, F. and Guzzetti, F. (Eds.): Geographical Information Systems in Assessing Natural Hazards, Kluwer Academic Publisher, Dordrecht, The Netherlands (1995), 353 pp., 1995.

Carrara, A., Cardinalli, M., Guzzetti, F., and Reichenbach, P.: GIS technology in mapping landslide hazard, in: Geographical Information Systems in Assessing Natural Hazard, edited by: Carrara, A. and Guzzetti, F., Kluwer Academic Publisher, 173-175, 1995.

20 Carrara, A., Guzzetti, F., Cardinali, M., and Reichenbach, P.: Use of GIS technology in the prediction and monitoring of landslide hazard, Nat. Hazards, 20, 117-135, 1999.

Castellanos Abella, E. A. and van Westen, C. J.: Qualitative landslide susceptibility assessment by multicriteria analysis: A case study from San Antonio del Sur, Guantanamo, Cuba Geomorph., 94, 453-466, 2008.

25 Cevik, E., and Topal, T.: GIS-based landslide susceptibility mapping for a problematic segment of the natural gas pipeline, Hendek (Turkey), Environ. Geol., 44, 949-962, 2003.

Chung, C. J. F. and Fabbri, A. G.: Probabilistic prediction models for landslide hazard mapping, Photogram. Eng. Remote Sens., 65, 1389-1399, 1999.

Clerici, A., Perego, S., Tellini, C., and Vescovi, P.: A procedure for landslide susceptibility zonation by the conditional analysis method, Geomorphology, 48, 349-364, 2002.

Creutzburg, N.: General geological map of Greece (Crete Island), 1:200.000, I.G.R.M., Athens, 1977. 
Dahal, R. K., Hasegawa, S., Nonomura, A., Yamanaka, M., Masuda, T., and Nishino, K.: GISbased weights-of-evidence modelling of rainfall-induced landslides in small catchments for landslide susceptibility mapping, Environ. Geol., 54, 311-324, 2008a.

Dahal, R. K., Hasegawa, S., Nonoumra, A., Yamanaka, M., Dhakal, S., and Paudyal, P.: Pre-

5 dictive modelling of rainfall-induced landslide hazard in the Lesser Himalaya of Nepal based on weights-of-evidence, Geomorphology, 102, 496-510, 2008b.

Dai, F. C. and Lee, C. F.: Landslide characteristics and slope instability modeling using GIS, Lantau Island, Hong Kong, Geomorphology. 42, 213-228, 2002.

Dai, F. C., Lee, C. F., and Zhang, X. H.: GIS-based geo-environmental evaluation for urban land-use planning: a case study, Eng. Geology, 61, 257-271, 2001.

Dai, F. C., Lee, C. F., and Ngai, Y. Y.: Landslide risk assessment and management: an overview, Eng. Geol., 64, 65-87, 2002.

Dikau, R., Cavallin, A., and Jager, S.: Databases and GIS for landslide research in Europe, Geomorphology, 15, 227-239, 1996.

15 Ercanoglu, M. and Gokceoglu, C.: Use of fuzzy relations to produce landslide susceptibility map of a landslide prone area (West Black Sea Region, Turkey), Eng. Geol., 75, 229-250, 2004.

Evans, N. C., Huang, S. W., and King, J. P.: The Natural Terrain Landslide Study - Phases I and II, Special Project Report SPR5/97, Geotechnical Engineering Office, Hong Kong, 1997.

Fall, M.: Standsicherheitsanalyse der Küstenhänge in Cap Manuel (Dakar, Senegal) mit Hilfe

20 ingenieurgeologisch-geotechnischer Untersuchungen und GIS-technologischer Methoden, Veröffentlichung Institut Geotechnik, Heft 2000-2, 187 pp., 2000.

Fall, M. and Azzam, R.: Ingenieurgeologische und numerische Standsicherheitsanalysen der Basaltkliffe in Dakar, Int. J. Felsbau, 19, 51-57, 2001a.

Fall, M. and Azzam, R.: An example of multi-disciplinary approach to landslide assessment in coastal area. International conference on landslide, Proceedings International Conference on Landslides: Causes Impacts and Countermeasures, Davos, Switzerland, Glückauf Verlag, 45-54, 2001b.

Fall, M., Dia, A., Fall, M., Gbaguidi, I., Lo, P. G., and Diop, I. N.: Un cas d'instabilité de pente naturelle: le versant des Madeleines-Presqu'île de Dakar (Sénégal): Analyse, Cartographie des risques et prévention, B. Eng. Geol. Environ., 53, 29-38, 1996.

Fall, M., Azam, R., and Noubactep, C.: A multi-method approach to study the stability of natural slopes and landslide susceptibility mapping, Eng. Geol., 82, 241-263, 2006.

Fell, R., Walker, B., and Finlay, P.: Estimating the probability of landsliding. Proc. 7th Austr. New Zeal. Conf. on Geomechanics, Adelaide, Institute of Engineers, Australia, Canberra, 304-311, 1996.

Fitrolakis, S.: The geologic structure of Crete, lectureship thesis, National Technical University of Athens, Department of Engineering and Metallurgy, Greece, 1980 (in Greek).

Ghosh, S., van Westen, C. J., Carranza, E. J. M., Ghosal, T. B., Sarkar, N. K., and Surendranath, M.: A quantitative approach for improving the BIS (Indian) method of medium-scale landslide susceptibility, J. Geol. Soc. India, 74, 625-638, 2009.

Gorsevski, P. V., Gessler, P., and Foltz, R. B.: Spatial prediction of landslide hazard using logistic regression and GIS, 4th Int. Conf. on Integrating GIS and Environmental Modeling, Proceedings, Banff, Alberta, Canada, 9 pp., 2000.

Guzetti, F., Carrarra, A., Cardinali, M., and Reichenbach, P.: Landslide hazard evaluation: a review of current techniques and their application in a multiscale study, Central Italy, Geomorphology, 31, 181-216, 1999.

15 Huang, R. and Li, Y.: Logical model of slope stability prediction in the Three Gorges Reservoir area, China, Proceedings of the Sixth International Symposium on Landslides-Glissements de terrain, Balkema Publishers, A.A., Christchurch, 977-981, 1992.

Hutchinson, J. and Chandler, M.: A preliminary landslide hazard zonation of the undercliff of the Isle of Wight, in: Slope Stability Engineering. Developments and Applications, edited by: Chandler, R., T. Telford, 197-206, 1991.

Institute of Geology and Mineral Exploration - I.G.M.E.: Geological map of Greece - Platanias Sheet (Scale 1:50.000), IGME, Athens, 1956.

Institute of Geology and Mineral Exploration - I.G.M.E.: Geological map of Greece - Alikianou Sheet (Scale 1:50.000), IGME, Athens, 1969.

25 Institute of Geology and Mineral Exploration - I.G.M.E.: Geological map of Greece - Kastelli Sheet (Scale 1:50.000), IGME, Athens, 1970.

Institute of Geology and Mineral Exploration - I.G.M.E.: Geological map of Greece - Khania Sheet (Scale 1:50.000), IGME, Athens, 1971.

Institute of Geology and Mineral Exploration - I.G.M.E.: Geological map of Greece - Sellia Sheet (Scale 1:50.000), IGME, Athens, 1982.

Institute of Geology and Mineral Exploration - I.G.M.E.: Geological map of Greece - Rethymno Sheet (Scale 1:50.000), IGME, Athens, 1988. 
Institute of Geology and Mineral Exploration - I.G.M.E.: Geological map of Greece - Vrisses Sheet (Scale 1:50.000), IGME, Athens, 1993a.

Institute of Geology and Mineral Exploration - I.G.M.E.: Geological map of Greece (Scale 1:500.000), IGME, Athens, 1993b.

5 Institute of Geology and Mineral Exploration - I.G.M.E.: Geological map of Greece - Palaeohora Sheet (Scale 1:50.000), IGME, Athens, 2002.

Kayastha, P., Dhital, M. R., and De Smedt, F.: Landslide susceptibility mapping using the weight of evidence method in the Tinau watershed, Nepal, Nat. Hazards, 63, 479-498, doi:10.1007/s11069-012-0163-z, 2012.

10 Komac, M.: A landslide susceptibility model using the analytical hierarchy process method and multivariate statistics in perialpine Slovenia, Geomorphology, 74, 17-28, 2006.

Koukis, G. and Ziourkas, C.: Slope instability phenomena in Greece: A statistical analysis, B. IAEG, 43, 47-60, 1991.

Koukis, G., Tsiambaos, G., and Sabatakakis, N.: Landslide movements in Greece: Engineering

15 geological characteristics and environmental consequences, in: Proceedings of International Symposium of Eng. Geol. and the Envar, IAEG, Balkema, Rotterdam, 789-792, 1997.

Kouli, M., Soupios, P., and Vallianatos, F.: Soil loss prediction using the revised universal soil loss equation (RUSLE) in a GIS framework, Chania, Northwestern Crete, Greece, Environ. Geol., 57, 483-497, 2009.

20 Kouli, M., Loupasakis, C., Soupios, P., and Vallianatos, F.: Landslide hazard zonation in high risk areas of Rethymno Prefecture, Crete Island, Greece, Nat. Hazards, 52, 599-621, 2010.

Krahl, J., Kaufmann, G., Kozur, H., Richter, D., Forster, O., and Heinritzi, F.: Neue Daten zur Biostratigraphie und zur tektonischen Lagerung der Phyllit-Gruppe und der Trypali Gruppe auf der Insel Kreta (Griechenland), Geol. Rundsch., 72, 1147-1166, 1983.

25 Kramer, S. L.: Geotechnical Earthquake Engineering, Prentice-Hall, Upper Saddle River, NJ (1996), 653 pp., 1996/

Lee, E. M. and Jones, D. K. C.: Landslide Risk Assessment, Thomas Telford, London, 454 pp., 2004.

Lee, S. and Choi, J.: Landslide susceptibility mapping using GIS and the weight-of-evidence model, Int. J. Geogr. Inf. Sci., 18, 789-814, 2004.

Lee, S. and Min, K.: Statistical analysis of landslide susceptibility at Yongin, Korea, Environ. Geol., 40, 1095-1113, doi:10.1007/s002540100310, 2001.

Lee, S., Choi, J., and Min, K.: Landslide susceptibility analysis and verification using the Bayesian probability model, Environ. Geol., 43, 120-131, 2002.

Lee, S., Choi, J., and Min, K.: Probabilistic landslide hazard mapping using GIS and remote sensing data at Boun, Korea, Int. J. Remote Sens., 25, 2037-2052, 2004a.

5 Lee, S., Ryu, J., Won, J., and Park, H.: Determination and application of the weight for landslide susceptibility mapping using an artificial neural network, Eng. Geol., 71, 289-302, 2004b.

Lee, S., Kim, Y. S., and Oh, H. J.: Application of a weights-of-evidence method and GIS to regional groundwater productivity potential mapping, J. Environ. Manage., 96, 91-105, 2012.

Leroi, E.: Landslide risk mapping: problems, limitation and developments. in: Landslide Risk

10 Assessment, edited by: Cruden, D. M. and Fell, R., Balkema, Rotterdam, 239-250, 1997.

Luzi, L., Pergalani, F., and Terlien, M. T. J.: Slope vulnerability to earthquakes at subregional scale, using probabilistic techniques and geographic information systems, Eng. Geol., 58, 313-336, 2000.

Makropoulos, K. C. and Burton, P. W.: Greek tectonics and seismicity, Tectonophysics, 106, 275-304, 1984.

Mathew, J., Jha, V. K., and Rawat, G. S.: Weights of evidence modeling for landslide hazard zonation mapping in part of Bhagirathi valley, Uttarakhand, Curr. Sci., 92, 628-638, 2007.

McKenzie, D. P.: Active tectonics of the Mediterranean region, Geophys. J. R. Astr. Soc., 5, 217-254, 1972.

20 Miles, S. B. and Ho, C. L.: Rigorous landslide hazard zonation using Newmark's method and stochastic ground motion simulation, Soil Dynam. Earthq. Eng., 18, 305-323, 1999.

Miles, S. B. and Keefer, D. K.: Evaluation of seismic slope-performance models using a regional case study, Environ. Eng. Geosci., 6, 25-39, 1999.

Mondal, S. and Maiti, R.: Landslide Susceptibility Analysis of Shiv-Khola Watershed, Darjiling:

25 A Remote Sensing \& GIS Based Analytical Hierarchy Process (AHP) J. Indian Soc. Remote Sens., 40, 483-496, 2012.

Moon, A., Olds, R., Wilson, R., and Burman, B.: Debris flow zoning at Montrose, Victoria, Proc. 6th Intern. Symp. on Landslides, 2, Balkema, Rotterdam, 2, 1015-1022, 1992.

Nash, D.: A comparative review of limit equilibrium methods of slope stability analysis, in: Slope Stability, edited by: Anderson, M. G. and Richards, K. J., Wiley, New York, 11-75, 1987.

Neuhäuser, B. and Terhorst, B.: Landslide susceptibility assessment using "weights-ofevidence" applied to a study area at the Jurassic escarpment (SW-Germany), Geomorphology, 86, 12-24, 2007. 
Ohlmacher, G. C. and Davis, J. C.: Using multiple logistic regression and GIS technology to predict landslide hazard in northeast Kansas, USA, Eng. Geol., 69, 331-343, 2003.

Papazachos, B. C. and Comninakis, P. E.: Geophysical and tectonic features of the Aegean arc, J. Geophys. Res., 76, 8517-8533, 1971.

5 Polemio, M. and Sdao, F.: The role of rainfall in the landslide hazard: the case of the Avigliano urban area (Southern Apennines, Italy), Eng. Geol., 53, 297-309, 1999.

Poli, S. and Sterlacchini, S.: Landslide representation strategies in susceptibility studies using Weights of Evidence modeling technique, Nat. Resour. Res., 16, 121-134, 2007.

Popescu, M.: A suggested method for reporting landslide causes, B. Eng. Geol. Environ., 50, 71-74, doi:10.1007/BF02594958, 1994.

Refice, A. and Capolongo, D.: Probabilistic modeling of uncertainties in earthquake-induced landslide hazard assessment, Comput. Geosci., 28, 735-749, 2002.

Regmi, N. R., Giardino, J. R., and Vitek, J. D.: Modeling susceptibility to landslides using the weight of evidence approach: Western Colorado, USA, Geomorphology, 115, 172-187, 2010.

Rezaei Moghaddam, M. H., Khayyam, M., Ahmadi, M., and Farajzadeh, M.: Mapping susceptibility landslide by using the weight-of-evidence model: a case study in Merek Valley, Iran, J. Appl. Sci., 7, 3342-3355, 2007.

Rossi, M., Guzzetti, F., Reichenbach, P., Mondini, P. R., and Peruccacci, S.: Optimal landslide

20 susceptibility zonation based on multiple forecasts, Geomorphology, 114, 129-142, 2010.

Saaty, T. L.: The Analytical Hierarchy Process, McGraw Hill, New York, 1980.

Saha, A. K., Gupta, R. P., and Arora, M. K.: GIS-based landslide hazard zonation in the Bhagirathi (Ganga) valley, Himalayas, Int. J. Remote Sens., 23, 357-369, 2002.

Sdao, F. and Simeone, V.: Mass movements affecting Goddess Mefitis sanctuary in Rossano di Vaglio (Basilicata, southern Italy), J. Cult. Herit., 8, 77-80, 2007.

Sharma, M. and Kumar, R.: GIS-based landslide hazard zonation: a case study from the Parwanoo area, Lesser and Outer Himalaya, H. P. India, Bull. Eng. Geol. Environ., 67, 129-137, 2008.

Siddle, H. J., Jones, D. B., and Payne, H. R.: Development of a methodology for landslip potential mapping in the Rhondda Valley, in: Slope stability engineering, edited by: Chandler, R. J., Thomas Telford, London, 137-142, 1991.

Spiegelhater, D. and Knill-Jones, R. P.: Statistical and knowledge approaches to clinical decision-support systems, with an application in gastroenterology, J. R. Stat. Soc., 147, 35$77,1984$.

Strahler, A. N.: Quantitative analysis of watershed geomorphology, Trans. Am. Geophys. Union, 38, 913-920, 1957.

Strahler, A. N.: Quantitative geomorphology of basins and channel networks, in: Handbook of Applied Hydrology, edited by: Chow, V. T., Mcgraw Hill Book Company, New York, 1964.

Suzen, M. L. and Doyuran, V.: Data driven bivariate landslide susceptibility assessment using geographical information systems: a method and application to Asarsuyu catchment, Turkey, Eng. Geol., 71, 303-321, 2004.

Tataris, A. and Christodoulou, C.: The Geological structure of Leuca Mountains, Bull. Geol. Soc. Greece, 6, 319-347, 1965.

Terlien, M. T. J., Van Asch, Th. W. J., and van Westen, C. J.: Deterministic modeling in GISbased landslide hazard assessment, in: Geographical Information Systems in Assessing Natural Hazards, edited by: Carrar, A. and Guzzetti, F., Kluwer, London, 57-77, 1995.

Terzaghi, K.: Mechanisms of landslides, Geological Society of America, Berkey Volume, 83123, 1950.

Thiery, Y., Sterlacchini, S., Malet, J. P., Puissant, A., Remaitre, A., and Maquaire, O.: Strategy to reduce subjectivity in landslide susceptibility zonation by GIS in complex mountainous environments, in: Proceedings of AGILE 2004: 7th AGILE conference on geographic information science, edited by: Toppen, F. and Prastacos, P., 29th April-1st May 2004, Heraklion, Greece, 623-634, 2004.

Thiery, Y., Malet, J.-P., Sterlacchini, S., Puissant, A., and Maquaire, O.: Landslide susceptibility assessment by bivariate methods at large scales: application to a complex mountainous environment, Geomorphology, 92, 38-59, 2007.

Tsiampaos, G.: Engineering geological characteristics of the Iraklion marls, Crete, PhD Thesis, Technical Chamber of Greece, Iraklion, 358 pp., 1989.

van Westen, C. J.: GIS in landslide hazard zonation: a review, with examples from the Andes of Colombia, in: Mountain environments and geographic information system, edited by: Price,

30 M. and Heywood, I., Taylor and Francis, London, 135-165, 1994.

van Westen, C. J. and Lulie Getahun, F.: Analyzing the evolution of the Tessina landslide using aerial photographs and digital elevation models, Geomorphology, 54, 77-89, 2003. 
van Westen, C. J., Rengers, N., and Soeters, R.: Use of geomorphological information in indirect landslide susceptibility assessment, Nat. Hazards, 30, 399-419, 2003.

Ward, T. J., Li, R. M., and Simons, D. B.: Use of a mathematical model for estimating potential landslide sites in steep forested drainage basins, IAHS Publication, 132, 21-41, 1981.

5 Wieczorek, G. F.: Landslide triggering mechanisms, Landslide: Investigation and Mitigation, Spec. Rep.-Transp. Res. Board, Nat. Acad. of Sciences, 247, 76-90, 1996.

Wieczorek, G. F., Mandrone, G., and DeCola, L.: The influence of hillslope shape on debrisflowinitiation, in: Debrisflow Hazards Mitigation: Mechanics, Prediction, and Assessment, edited by: Chen, C. L., American Society of Civil Engineers, New York, 21-31, 1997.

10 WP/WLI (International Geotechnical Societies' UNESCO Working Party on World Landslide Inventory): A suggested method for reporting landslides causes. Bulletin of the International Association of Engineering Geology, 50, 71-74, 1994.

Wu, S., Shi, L., Wang, R., Tan, C., Hu, D., Mei, Y., and Xu, R.: Zonation of the landslide hazard in the forereservoir region of the Three Gorges Project on the Yangtze River, Eng. Geol., 59, 51-58, 2001.

Xu, C., Xu, X., Lee, Y. H. , Tan, X., Yu, G., and Dai, F.: The 2010 Yushu earthquake triggered landslide hazard mapping using GIS and weight of evidence modeling, Environ. Earth Sci., 66, 1603-1616, doi:10.1007/s12665-012-1624-0, 2012.

Yalcin, A.: GIS-based landslidesusceptibility mapping using analytical hierarchy process and bivariate statistics in Ardesen (Turkey), Comparisons of results and confirmations, Catena, 72, 1-12, 2008.

Table 1. The causative factors and the corresponding weighting and rating values adopted in this study for the extraction of the Landslide Hazard Index (LHI) with the WLC method.

\begin{tabular}{|c|c|c|c|c|c|c|c|c|}
\hline Data layer & Class & Rate & Data layer & Class & Rate & Data layer & Class & Rate \\
\hline \multirow{5}{*}{$\begin{array}{l}\text { Lithology } \\
\text { Weight: } 10\end{array}$} & Loose quaternary deposits & 8 & \multirow{19}{*}{$\begin{array}{l}\text { Streams } \\
\text { proximity } \\
\text { Weight: } 0.8 \text { * } \\
\text { LR }\end{array}$} & \multicolumn{2}{|c|}{ Streams of 1 st Order } & \multirow{3}{*}{$\begin{array}{l}\text { Rainfall Weight: } \\
0.8^{*} \mathrm{LR}\end{array}$} & $1400-1200$ & 10 \\
\hline & Neogene & 7 & & $<10 \mathrm{~m}$ & 7 & & $1200-1000$ & 9 \\
\hline & Limestones-Marbles & 6 & & $10-20 \mathrm{~m}$ & 5 & & $1000-800$ & 8 \\
\hline & Flysch & 10 & & $>20 \mathrm{~m}$ & 0 & \multirow{4}{*}{$\begin{array}{l}\text { Roads } \\
\text { Proximity } \\
\text { Weight: } 0.8^{*} \\
\text { LR }\end{array}$} & $<20 \mathrm{~m}$ & 10 \\
\hline & Phyllites-Quartzites & 9 & & Streams of & 2nd Order & & $20-50 \mathrm{~m}$ & 8 \\
\hline \multirow{6}{*}{$\begin{array}{l}\text { Faults Proximity } \\
\text { Weight: } 0.9^{*} \\
\text { LR }\end{array}$} & Fault & & & $<20 \mathrm{~m}$ & 8 & & $50-100 \mathrm{~m}$ & 6 \\
\hline & $<100 \mathrm{~m}$ & 6 & & $20-50 \mathrm{~m}$ & 6 & & $>100 \mathrm{~m}$ & 0 \\
\hline & $100-200 \mathrm{~m}$ & 4 & & $>50 \mathrm{~m}$ & 0 & \multirow{5}{*}{$\begin{array}{l}\text { Slope Angle } \\
\text { Weight: } 0.9 \text { * } \\
\text { LR }\end{array}$} & $>45^{\circ}$ & 10 \\
\hline & $>200 \mathrm{~m}$ & 0 & & Streams of & 3rd Order & & $31-45^{\circ}$ & 9 \\
\hline & Sparsely vegetated areas & 10 & & $<50 \mathrm{~m}$ & 9 & & $16-30^{\circ}$ & 8 \\
\hline & Artificial and Natural grasslands & 9 & & $50-100 m$ & 7 & & $6-15^{\circ}$ & 3 \\
\hline \multirow{6}{*}{$\begin{array}{l}\text { Landuse/Landcover } \\
\text { Weight: } 0.9^{*} \mathrm{LR}\end{array}$} & Heterogeneous agricultural areas & 8 & & $>100 \mathrm{~m}$ & 0 & & $0-5^{\circ}$ & 1 \\
\hline & Arable land & 7 & & \multicolumn{3}{|c|}{ Streams of 4 th Order } & & \\
\hline & Discontinuous urban fabric & 6 & & $<20 \mathrm{~m}$ & 7 & & & \\
\hline & Sclerophyllous vegetation & 5 & & $20-50 \mathrm{~m}$ & 5 & & & \\
\hline & Permanent crops & 4 & & $>50 \mathrm{~m}$ & 0 & & & \\
\hline & Coniferous forest - Transitional woodland & 2 & & Streams of & 5th Order & & & \\
\hline \multirow{11}{*}{$\begin{array}{l}\text { Elevation } \\
\text { Weight: } 0.6 \text { * } \\
\text { LR }\end{array}$} & $>1401 \mathrm{~m}$ & 2 & & $<10 \mathrm{~m}$ & 4 & & & \\
\hline & $1301-1400 \mathrm{~m}$ & 4 & & $10-20 \mathrm{~m}$ & 2 & & & \\
\hline & $1201-1300 \mathrm{~m}$ & 6 & \multirow{9}{*}{$\begin{array}{l}\text { Slope Aspect } \\
\text { Weight: } 0.6^{*} \\
\text { LR }\end{array}$} & w & 9 & & & \\
\hline & $1101-1200 \mathrm{~m}$ & 7 & & NW & 10 & & & \\
\hline & $1001-1100 \mathrm{~m}$ & 8 & & $N$ & 9 & & & \\
\hline & $901-1000 \mathrm{~m}$ & 9 & & $\mathrm{NE}$ & 6 & & & \\
\hline & $801-900 \mathrm{~m}$ & 10 & & $E$ & 4 & & & \\
\hline & $701-800 \mathrm{~m}$ & 9 & & SE & 2 & & & \\
\hline & $601-700 \mathrm{~m}$ & 8 & & $\mathrm{~s}$ & 4 & & & \\
\hline & $501-600 \mathrm{~m}$ & 7 & & sw & 6 & & & \\
\hline & $<500 \mathrm{~m}$ & 6 & & Flat & 0 & & & \\
\hline
\end{tabular}

LR: Lithology Rating. 
Table 2. The parameters obtained after the application of WoE method for the extraction of the Landslide Hazard Index (LHI). Italics are used for maximum and minimum $C$ values i.e. for the classes of maximum positive and negative relation with landslide phenomena. Bold type show the major landslide causal factors based on weight values.

\begin{tabular}{|c|c|c|c|c|c|c|c|c|c|}
\hline Causative Factors & Area $\left(\mathrm{km}^{2}\right)$ & Landslides & $w^{+}$ & $S^{2}\left(W^{+}\right)$ & $w^{-}$ & $S^{2}\left(W^{-}\right)$ & c & $S(C)$ & $C / S(C)$ \\
\hline \multicolumn{10}{|c|}{ Slope Angle } \\
\hline $0-5^{\circ}$ & 433.209 & & -0.9863 & 0.4111 & 0.1366 & 0.1149 & -1.1229 & 0.4269 & -2.6307 \\
\hline 6-15 & $\begin{array}{l}403.209 \\
741.664\end{array}$ & $\begin{array}{l}0 \\
26\end{array}$ & $\begin{array}{l}-0.9003 \\
-0.0359\end{array}$ & 0.1996 & $\begin{array}{l}0.1300 \\
0.0162\end{array}$ & 0.1327 & $\begin{array}{l}-1.1229 \\
-0.0522\end{array}$ & $\begin{array}{l}0.2397 \\
0.2397\end{array}$ & $\begin{array}{l}-2.0307 \\
-0.2176\end{array}$ \\
\hline $16-30^{\circ}$ & $\begin{array}{l}81.00269 \\
810.269\end{array}$ & $\begin{array}{l}20 \\
42\end{array}$ & $\begin{array}{r}-0.0359 \\
0.3727\end{array}$ & $\begin{array}{l}0.1585 \\
0.1585\end{array}$ & $\begin{array}{l}-0.2654 \\
-\end{array}$ & 0.1547 & $\begin{array}{r}-0.0522 \\
0.6381\end{array}$ & 0.2214 & 2.8815 \\
\hline $31-45^{\circ}$ & 296.034 & 9 & -0.1832 & 0.3385 & 0.0241 & 0.1169 & -0.2073 & 0.3581 & -0.5788 \\
\hline$>45^{\circ}$ & 60.957 & 2 & -0.1045 & 0.7190 & 0.0027 & 0.1118 & -0.1071 & 0.7276 & -0.1472 \\
\hline \multicolumn{10}{|c|}{ Slope Aspect } \\
\hline Flat & 8.9160 & 0 & 0.0000 & 0.0000 & 0.0000 & 0.0000 & 0.0000 & 0.0000 & 0.0000 \\
\hline $\mathrm{N}$ & 290.3968 & 8 & -0.2847 & 0.3585 & 0.0348 & 0.1162 & -0.3195 & 0.3769 & -0.8477 \\
\hline $\mathrm{NE}$ & 300.1464 & 9 & -0.1974 & 0.3384 & 0.0262 & 0.1169 & -0.2236 & 0.3581 & -0.6244 \\
\hline E & 316.1248 & 4 & -1.0779 & 0.5032 & 0.1006 & 0.1134 & -1.1785 & 0.5158 & -2.2848 \\
\hline SE & 282.4676 & 10 & -0.0257 & 0.3220 & 0.0035 & 0.1176 & -0.0292 & 0.3428 & -0.0852 \\
\hline $\mathrm{s}$ & 256.8408 & 10 & 0.0730 & 0.3226 & -0.0093 & 0.1176 & 0.0824 & 0.3433 & 0.2400 \\
\hline sW & 262.9152 & 12 & 0.2390 & 0.2955 & -0.0343 & 0.1192 & 0.2733 & 0.3186 & 0.8579 \\
\hline w & 310.2024 & 15 & 0.2996 & 0.2647 & -0.0540 & 0.1216 & 0.3536 & 0.2913 & 1.2138 \\
\hline$N W$ & 314.1232 & 17 & 0.4183 & 0.2494 & -0.0820 & 0.1234 & 0.5003 & 0.2782 & 1.7981 \\
\hline \multicolumn{10}{|c|}{ Slope curvature } \\
\hline Concave & 1031.2840 & 64 & 0.5636 & 0.1291 & -0.8386 & 0.2200 & 1.4021 & 0.2551 & 5.4974 \\
\hline Flat & 287.2132 & 1 & -2.3775 & 1.0017 & 0.1238 & 0.1114 & -2.5013 & 1.0079 & $\begin{array}{r}-2.4816 \\
\end{array}$ \\
\hline Convex & 1023.6360 & 20 & -0.6365 & 0.2258 & 0.3199 & 0.1272 & -0.9563 & 0.2592 & -3.6898 \\
\hline \multicolumn{10}{|c|}{ Unified Geological Formations } \\
\hline Flysch & 39.67520 & 4 & 1.0603 & 0.5273 & -0.0314 & 0.1125 & 1.0917 & 0.5392 & 2.0248 \\
\hline Neogen & $\begin{array}{l}396.92880 \\
382.9280\end{array}$ & $\begin{array}{l}4 \\
5\end{array}$ & $\begin{array}{r}.0003 \\
-1.0873\end{array}$ & 0.4501 & $\begin{array}{r}-0.0314 \\
0.1294\end{array}$ & 0.1135 & -1.2167 & 0.4642 & $\begin{array}{r}2.0240 \\
-2.6210\end{array}$ \\
\hline Phyllites-Q & 516.83120 & & 1.1995 & 0.1383 & -0.9269 & 0.1939 & 2.1264 & 0.2382 & 8.9270 \\
\hline $\begin{array}{l}\text { Pnymos Carb } \\
\text { Pindos }\end{array}$ & $\begin{array}{r}516.83120 \\
12.91720\end{array}$ & $\begin{array}{r}59 \\
0\end{array}$ & 0.0000 & 0.0000 & $\begin{array}{r}-0.9209 \\
0.0000\end{array}$ & 0.0000 & $\begin{array}{l}2.1 .004 \\
0.0000\end{array}$ & 0.0000 & $\begin{array}{l}8.9270 \\
0.0000\end{array}$ \\
\hline $\begin{array}{l}\text { Plattenkalk Limestones } \\
\text { Planton }\end{array}$ & 624.70840 & 4 & -1.7961 & 0.5016 & 0.2813 & 0.1132 & $\begin{array}{l}0.0774 \\
-2.074\end{array}$ & 0.5142 & $\begin{array}{l}-.00398 \\
-4.0398\end{array}$ \\
\hline $\begin{array}{l}\text { Quaternary Deposits } \\
\text { Quats }\end{array}$ & $\begin{array}{l}624.10840 \\
278.53120\end{array}$ & $\begin{array}{l}4 \\
7\end{array}$ & $\begin{array}{l}-1.1961 \\
-0.4097\end{array}$ & 0.3828 & $\begin{array}{l}0.0459 \\
0.0459\end{array}$ & 0.1148 & $\begin{array}{l}-2.07 / 4 \\
-0.4556\end{array}$ & $\begin{array}{l}0.3996 \\
0.396\end{array}$ & $\begin{array}{l}-4.0398 \\
-1.1400\end{array}$ \\
\hline $\begin{array}{l}\text { Quater } \\
\text { Tripolis } \\
\end{array}$ & 145.84320 & 1 & $\begin{array}{l}-0.4097 \\
-1.7272\end{array}$ & $\begin{array}{l}0.388 \\
1.0034\end{array}$ & $\begin{array}{l}0.0459 \\
0.0559\end{array}$ & 0.1107 & $\begin{array}{l}-0.4556 \\
-1.7831\end{array}$ & $\begin{array}{l}0.0996 \\
1.0095\end{array}$ & $\begin{array}{l}-1.1400 \\
-1.7663\end{array}$ \\
\hline Trypalion Carbonates & 295.12680 & 6 & -0.6266 & 0.4125 & 0.0676 & 0.1141 & -0.6942 & 0.4280 & -1.6222 \\
\hline \multicolumn{10}{|c|}{ Rivers proximity } \\
\hline $0-20 \mathrm{~m}$ & 47.6776 & 3 & 1.1189 & 0.5964 & -0.0240 & 0.1109 & 1.1429 & 0.6066 & 1.8840 \\
\hline $20-5$ & 40.8712 & 3 & 1.2842 & 0.5998 & -0.0258 & 0.1109 & 1.3100 & 0.6100 & 2.1476 \\
\hline $50-100 \mathrm{~m}$ & 88.6980 & 6 & 1.1963 & 0.4228 & -0.0510 & 0.1130 & 1.2473 & 0.4376 & 2.8501 \\
\hline$>100 \mathrm{~m}$ & 3829.6956 & 74 & -0.1072 & 0.1174 & 1.1972 & 0.2990 & -1.3044 & 0.3212 & -4.0612 \\
\hline \multicolumn{10}{|c|}{ Elevation } \\
\hline $0-2 C$ & 679.8496 & 16 & -0.4463 & 0.2530 & 0.1398 & 0.1230 & -0.5860 & 0.2813 & -2.0833 \\
\hline & 437.9756 & 32 & 0.7386 & 0.1836 & -0.2741 & 0.1393 & 1.0127 & 0.2305 & 4.3939 \\
\hline $400-9$ & 747.9124 & 30 & 0.1040 & 0.1863 & -0.0525 & 0.1372 & 0.1565 & 0.2314 & 0.6765 \\
\hline $900-1400$ & 287.0952 & 7 & -0.4100 & 0.3827 & 0.0466 & 0.1154 & -0.4566 & 0.3997 & -1.1423 \\
\hline $1400-2600$ & 189.3004 & 0 & 0.0000 & 0.0000 & 0.0000 & 0.0000 & 0.0000 & 0.0000 & 0.0000 \\
\hline
\end{tabular}

Table 2. Continued.

\begin{tabular}{|c|c|c|c|c|c|c|c|c|c|}
\hline Causative Factors & Area $\left(\mathrm{km}^{2}\right)$ & Landslides & $w^{+}$ & $S^{2}\left(W^{+}\right)$ & $w^{-}$ & $S^{2}\left(W^{-}\right)$ & $c$ & $S(C)$ & $C / S(C)$ \\
\hline \multicolumn{10}{|c|}{ Faults proximity } \\
\hline $0-100 \mathrm{~m}$ & 419.2144 & 13 & 0.3304 & 0.2818 & -0.0489 & 0.1183 & 0.3793 & 0.3056 & 1.2411 \\
\hline $100-200 \mathrm{~m}$ & 318.4616 & 6 & -0.1804 & 0.4121 & 0.0149 & 0.1131 & -0.1954 & 0.4274 & -0.4571 \\
\hline $200-300 m$ & 259.6284 & 11 & 0.6542 & 0.3081 & -0.0681 & 0.1167 & 0.7223 & 0.3295 & 2.1923 \\
\hline $300-400 m$ & 219.5544 & 11 & 0.8300 & 0.3094 & -0.0795 & 0.1167 & 0.9095 & 0.3306 & 2.7507 \\
\hline$>400 \mathrm{~m}$ & 2608.4212 & 45 & -0.2701 & 0.1504 & 0.4161 & 0.1589 & -0.6863 & 0.2188 & -3.1371 \\
\hline \multicolumn{10}{|c|}{ Land Use } \\
\hline Arable land & 6.6524 & 0 & 0.0000 & 0.0000 & 0.0000 & 0.0000 & 0.0000 & 0.0000 & 0.0000 \\
\hline Ittural vegetated areas & & 0 & & & 0.0000 & & 0000 & 0.0000 & 0.0000 \\
\hline Fores & 180.4356 & 11 & 0.5087 & 11 & -0.0568 & 0.1176 & 0.5656 & 0.3326 & 1.7004 \\
\hline & 286.4256 & 15 & 0.3477 & 0.2652 & -0.0602 & 0.1208 & 0.4079 & 0.2915 & 1.3994 \\
\hline & & 0 & & 0.0000 & 0.0000 & & 0.0000 & 0.0000 & 0.0000 \\
\hline & & 0 & & 0 & 0.0 & & 0.0000 & 0.0000 & 0.0000 \\
\hline & & 0 & & & & & 0.0000 & & \\
\hline & 125.46 & 4 & -0.1700 & 32 & 1 & 0.1126 & -0.1791 & 0.5205 & -0.3441 \\
\hline & 7.74 & 0 & 0.0000 & 00 & 0.0000 & 0 & 0.0000 & 0.0000 & 0.0000 \\
\hline Per & & 13 & -0.1975 & & 0 037 & & & & -0.7749 \\
\hline oaceous ves & 122 & 42 & -0.0932 & 0. & 0.0979 & 0.1540 & -0.1912 & 0.2199 & -0.8693 \\
\hline Urban fa & 26.7620 & 1 & -0.0056 & 1.0192 & 0.0001 & 0.1106 & -0.0056 & 1.0252 & -0.0055 \\
\hline \multicolumn{10}{|c|}{ Rainfall } \\
\hline $800-1000 \mathrm{~mm}$ & 626.7776 & 39 & 0.5664 & 0.1654 & -0.3124 & 0.1495 & 0.8788 & 0.2229 & 3.9426 \\
\hline & & 33 & -0.0840 & 0.1771 & 0.0572 & 0.1414 & -0.1412 & 0.2266 & -0.6231 \\
\hline $1200-14$ & 729.2828 & 13 & -0.7299 & 0.2799 & 0.2158 & 0.1206 & -0.9457 & 0.3047 & -3.1035 \\
\hline \multicolumn{10}{|c|}{ Roads proximity } \\
\hline & & 28 & & & & & & & \\
\hline & 181.28 & 2 & -1.2288 & 0.7110 & 0.0593 & 0.1113 & -1.2880 & 0.7197 & -1.7897 \\
\hline$>500 \mathrm{~m}$ & 2104.0160 & 56 & -0.3322 & 0.1354 & 1.3302 & 0.1953 & -1.6624 & 0.2377 & -6.9947 \\
\hline
\end{tabular}




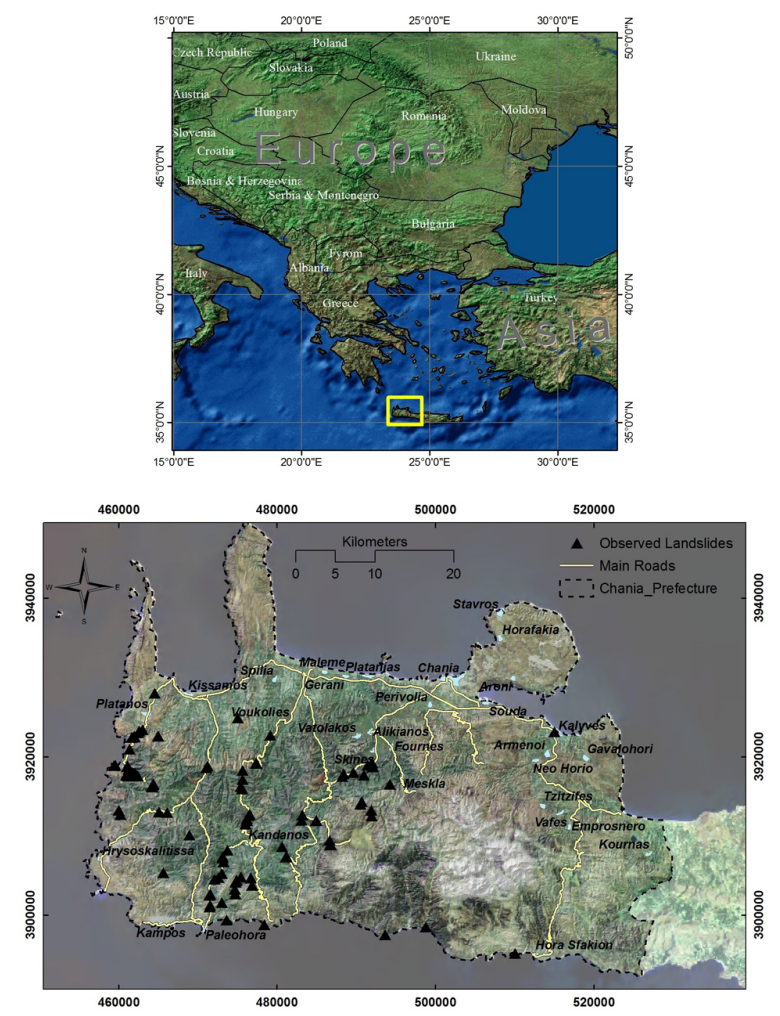

Fig. 1. Location maps of the area under investigation.

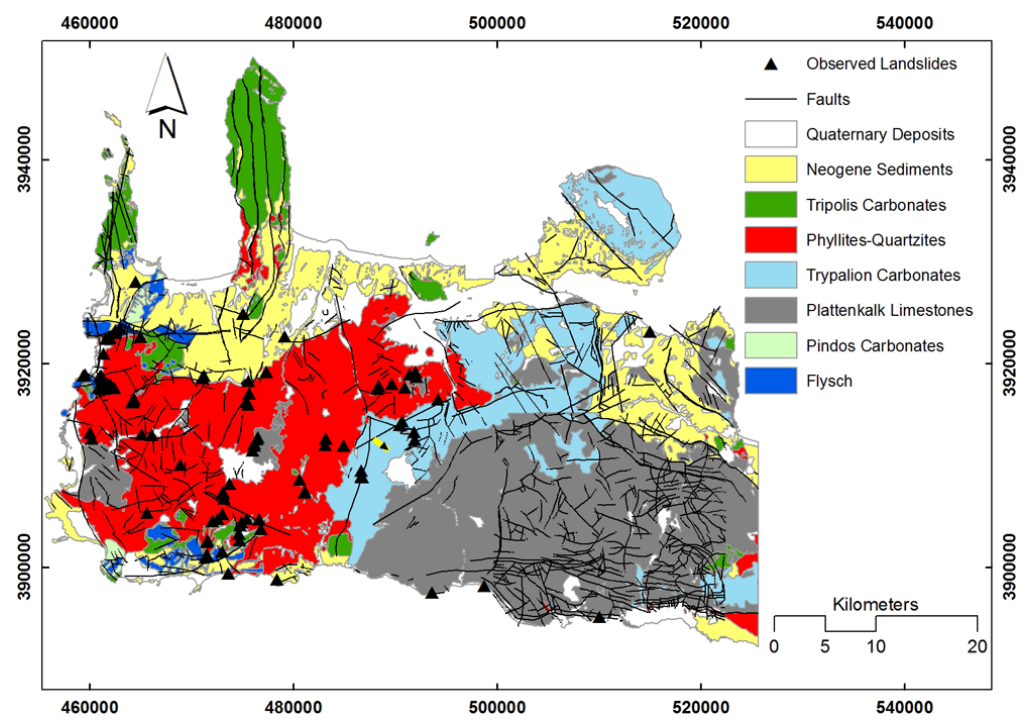

Fig. 2. Geological map of the study area. 

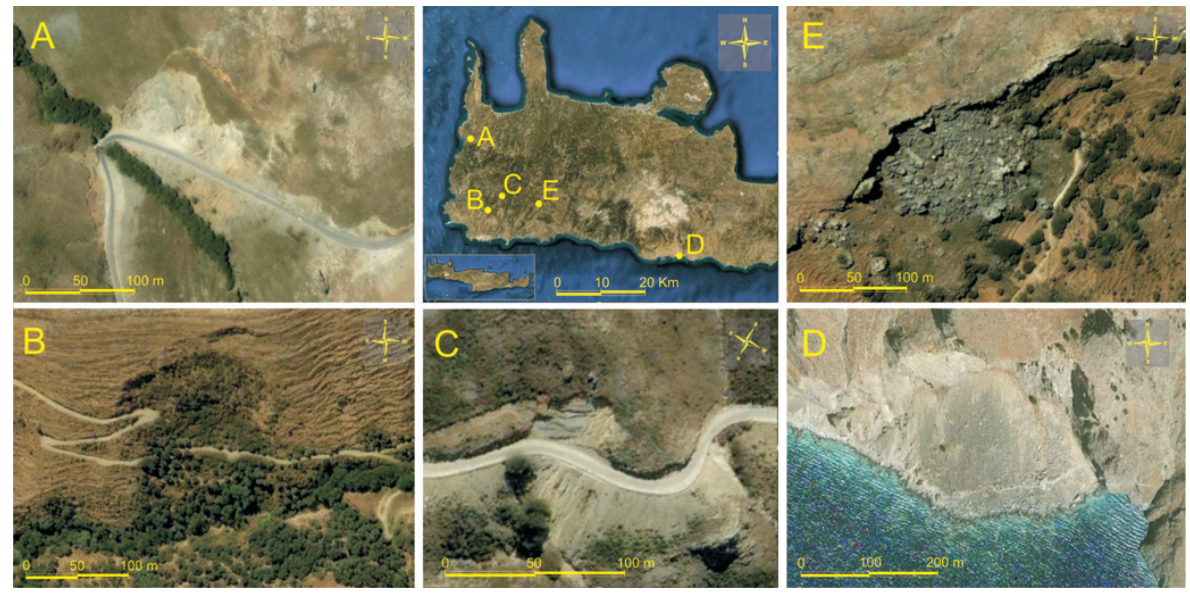

Fig. 3. Satellite pictures (taken from Google Earth) depicting the location of extensive landslides at the Chania Prefecture. (A), (B) and (C) indicate transitional landslides occurring at the Phyllites-Quartzites series. In (D) a domino of successive plane and wedge failures, in Plattenkalk Limestones, caused a $400 \mathrm{~m}$ wide cone of debris along the coastline is presented. (E) presents extensive rockfalls along the overthrust of Tripolis carbonates over the PhyllitesQuartzites series.

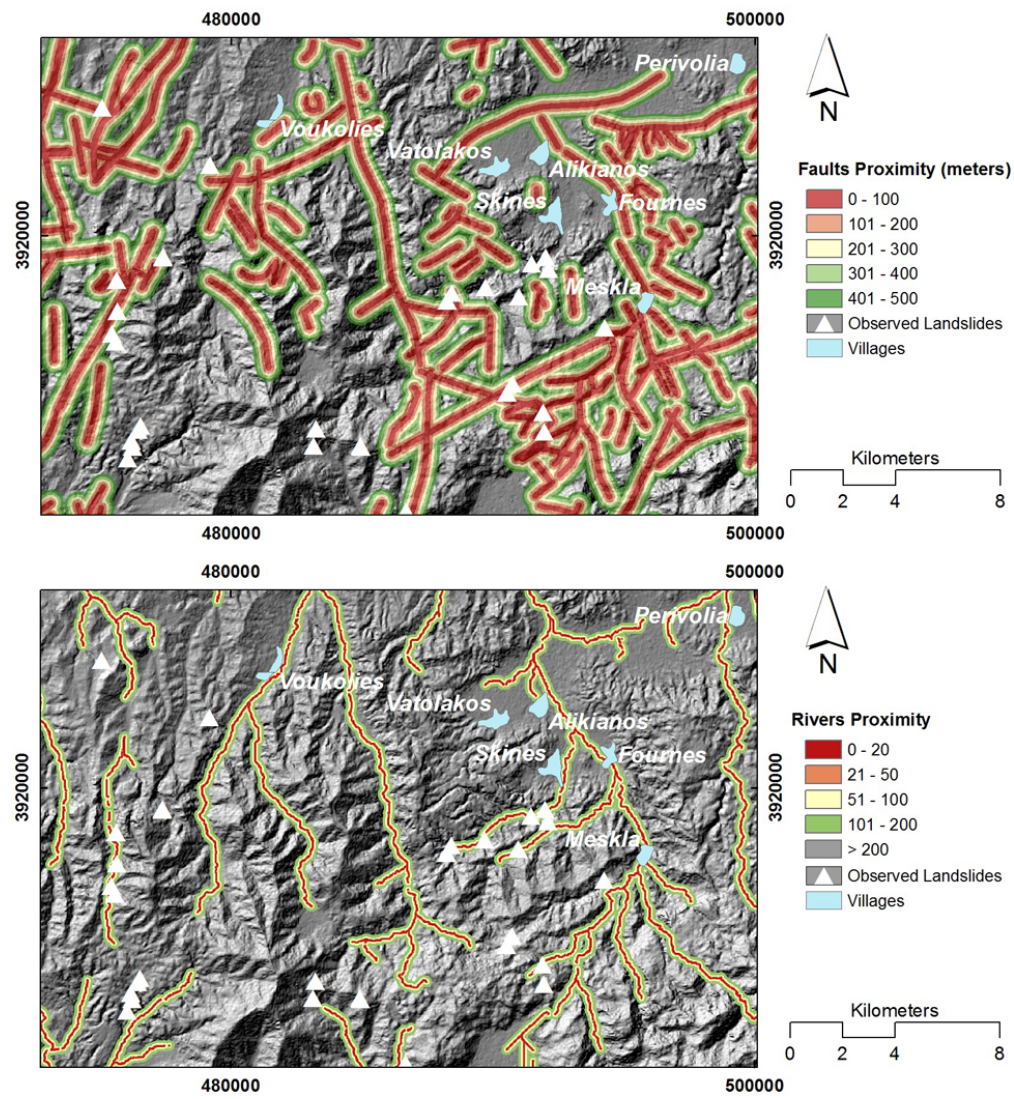

Fig. 4. Details of the faults and rivers proximity maps. 


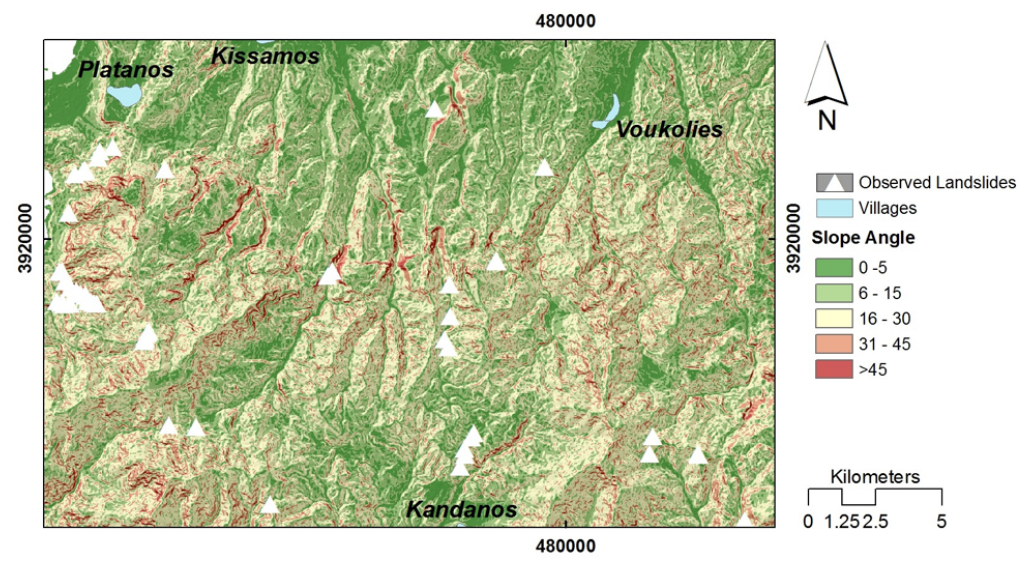

Fig. 5. Detail of the slope map of the Chania Prefecture.

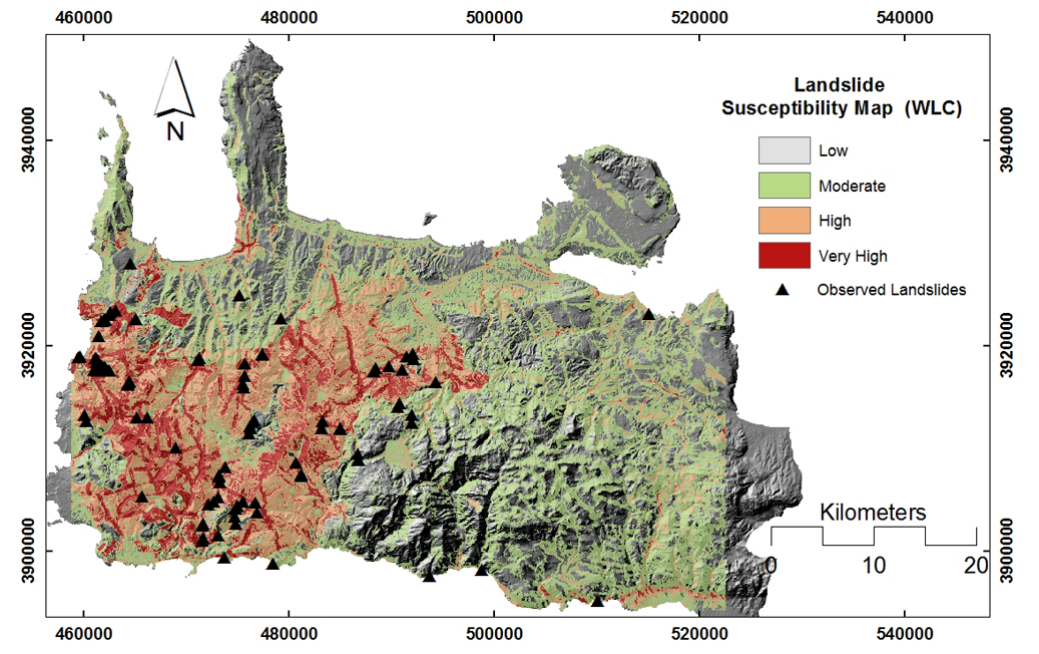

Fig. 6. The landslide susceptibility map of Chania Prefecture extracted with the WLC method. 


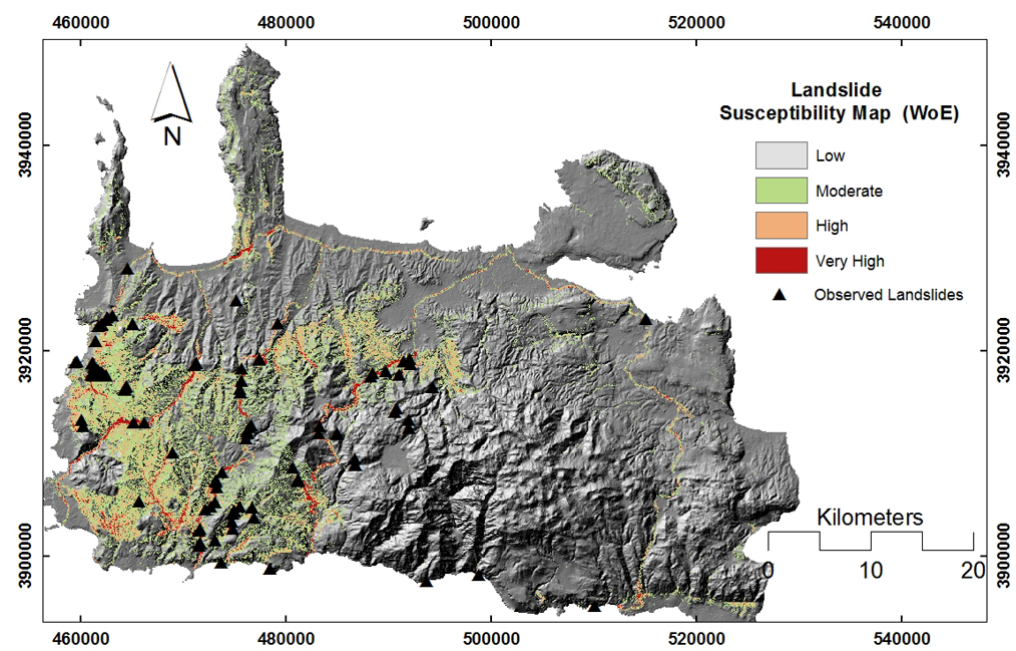

Fig. 7. The landslide susceptibility map of Chania Prefecture extracted with the WoE method.

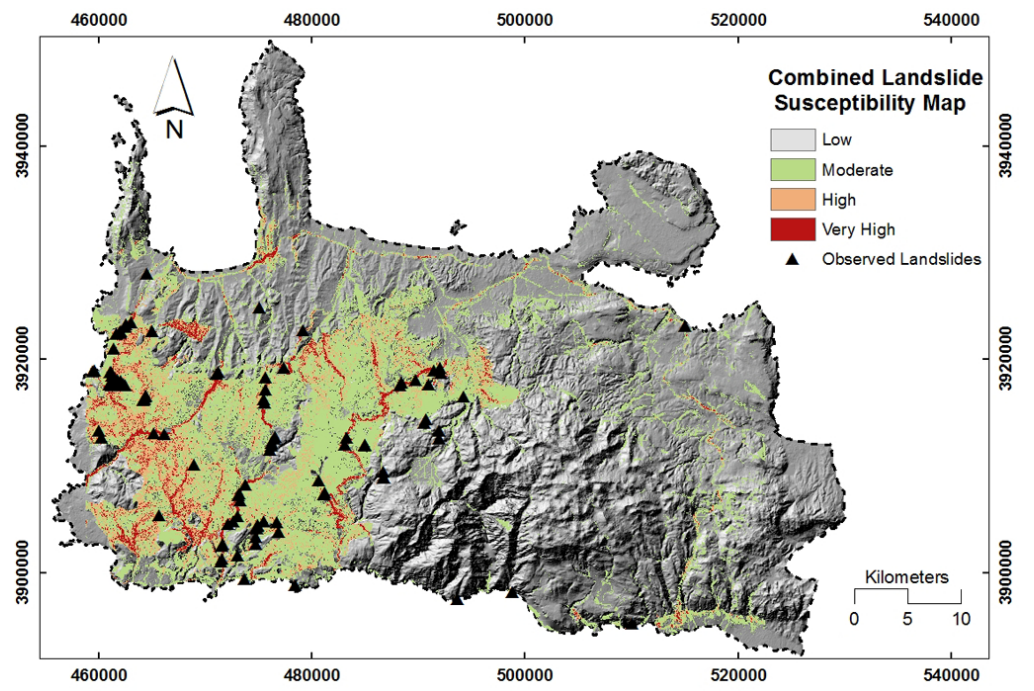

Fig. 8. The landslide susceptibility map resulted from the combination of the two susceptibility models. 


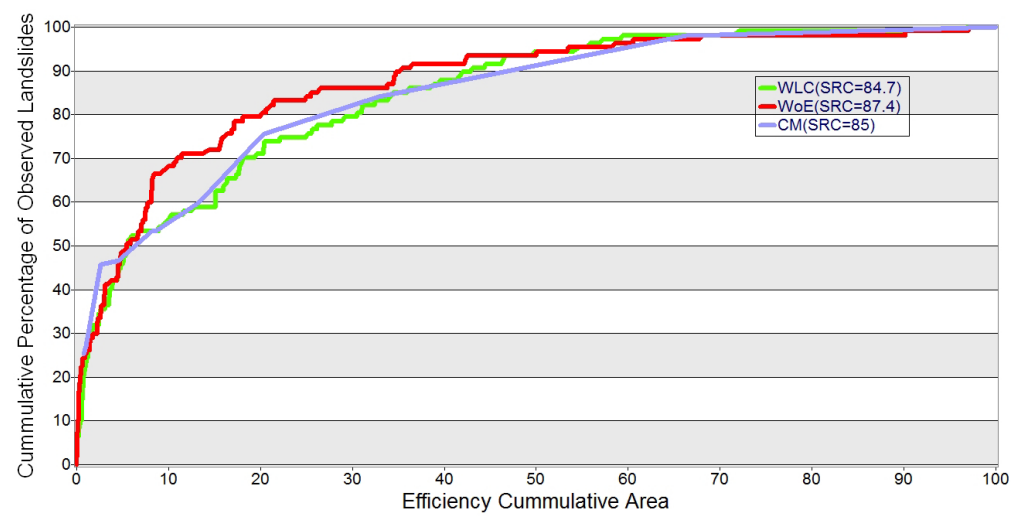

Fig. 9. Success rate curves showing cumulative percentage of observed landslide occurrences versus cumulative percentage of decreasing landslide susceptibility index value. 